\title{
Stratigraphy, Sedimentology, and Volume of Sediments Behind a Dam Relic on the Muskegon River, Big Rapids, Michigan
}

U.S. Geological Survey

Water-Resources Investigations Report 97-4069

Prepared in cooperation with the CITY OF BIG RAPIDS

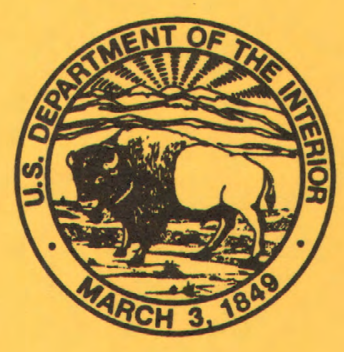





\section{Stratigraphy, Sedimentology, and Volume of Sediments Behind a Dam Relic on the Muskegon River, Big Rapids, Michigan}

\section{By D.B. WESTJOHN}

\section{U.S. Geological Survey}

Water-Resources Investigations Report 97-4069

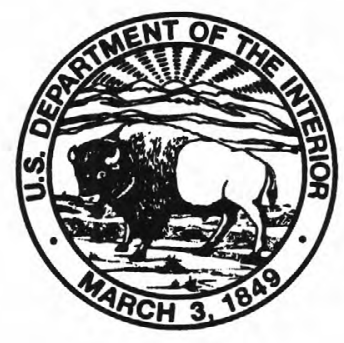




\title{
U.S. DEPARTMENT OF THE INTERIOR BRUCE BABBITT, Secretary
}

\author{
U.S. GEOLOGICAL SURVEY \\ Gordon P. Eaton, Director
}

For additional information write to:

Copies of this report can be purchased from:

Chief, Michigan District

U.S. Geological Survey

U.S. Geological Survey

Water Resources Division

Branch of Information Services

6520 Mercantile Way, Suite 5

Box 25286

Lansing, MI 48911

Federal Center

Denver, CO 80225-0286 


\section{CONTENTS}

Abstract
Introduction
Methodrogeologic Setting.
Collection of Sediment Cores
Ground-Penetrating Radar Profiles
Stratigraphy and Sedimentology
Glacial Till
Alluvium Deposited Prior to Dam Construction
Lacustrine Deposits
Estimate of Sediment Volume in the Lower Impoundment
Summary
References Cited

\section{FIGURES}

1,2. Maps showing:

1. State of Michigan, Mecosta County, and city of Big Rapids, Michigan

2. Data-collection sites and relevant features in the study area, Muskegon River, near Big Rapids, Michigan

3. Example graphic log of ground-penetrating radar (GPR) profile of the Muskegon River near Big Rapids, Michigan.

4. Stratigraphic relation of geologic units in the study area, interpreted on the basis of cores from boreholes, Muskegon River near Big Rapids, Michigan.

5. Map showing line of equal composite thickness of lacustrine sediments and younger coarse alluvial fill captured behind the dam relic on the Muskegon River.

\section{TABLES}

1. Lithologic descriptions of sediment cores collected at sites in the Muskegon River, Big Rapids, Michigan ........

2. Sieve analysis of sediment cores collected at sites upstream of dam relic on the Muskegon River, Big Rapids, Michigan ....

3. Altitude of stream surface, sediment/water interface, and base of fill, and thickness of post-1966 fill, thickness of 1916-66 fill, and total thickness of fill at borehole sites in the impoundment behind the dam relic on the Muskegon River, Big Rapids, Michigan

4. Weighted average of sediment-size fractions of post-1966 alluvium in the Muskegon River, Big Rapids, Michigan.

5. Estimate of volume of sediment in the lower impoundment area, Muskegon River, Big Rapids, Michigan 
CONVERSION FACTORS AND VERTICAL DATUM

\section{CONVERSION FACTORS}

\begin{tabular}{rll}
\hline Multiply & By & To obtain \\
\hline cubic foot per second $\left(\mathrm{ft}^{3} / \mathrm{s}\right)$ & 0.02832 & cubic meter per second \\
cubic yard $\left(\mathrm{yd}^{3}\right)$ & 0.7646 & cubic meter \\
foot $(\mathrm{ft})$ & 0.3048 & meter \\
mile $(\mathrm{mi})$ & 1.609 & kilometer \\
square foot $\left(\mathrm{ft}^{2}\right)$ & 0.09290 & square meter \\
square mile $\left(\mathrm{mi}^{2}\right)$ & 2.590 & square kilometer \\
yard $(\mathrm{yd})$ & 0.9144 & meter \\
\hline
\end{tabular}

Specific conductance is given in microsiemens per centimeter at 25 degrees Celsius $\left(\mu \mathrm{S} / \mathrm{cm}\right.$ at $\left.25^{\circ} \mathrm{C}\right)$.

\section{VERTICAL DATUM}

Sea level: In this report, "sea level" refers to the National Geodetic Vertical Datum of 1929 (NGVD of 1929)-a geodetic datum derived from a general adjustment of the first-order level nets of the United States and Canada, formerly called Sea Level Datum of 1929. 


\title{
Stratigraphy, Sedimentology, and Volume of Sediments Behind a Dam Relic on the Muskegon River, Big Rapids, Michigan
}

\author{
By D.B. Westjohn
}

\section{Abstract}

The proposed removal of the remnants of a hydroelectric dam in the Muskegon River at Big Rapids, Michigan, will potentially affect flow of the river at the city's water intake system. Fifteen boreholes were augered in bottom sediments in the river just upstream from the dam relic, and streambottom profiles were made using ground-penetrating radar. Data from boreholes show that sediments captured by the dam foundation were deposited in two distinctly different sedimentary environments. Sediments that overlie the pre-dam channel surface consist of lacustrine clay, wood chips, silt, and sand. These lacustrine sediments are interbedded in a cyclical fashion, and they were deposited under low flow to stagnant water conditions during 1916-66, when a 17-foot-tall hydroelectric dam was in place. Demolition of the upper 13 feet of this dam in 1966 resulted in erosion of most of the lacustrine sediments, and subsequent deposition of coarser alluvium in the impoundment behind the remaining dam foundation.

Lacustrine sediments are present in the active part of the stream channel and extend from the dam foundation to about 1,300 feet upstream. The composite thickness of lacustrine sediments and overlying coarser alluvium was determined from sediment cores collected from the boreholes. The volume of these sediments is estimated to be about 19,000 cubic yards.

\section{INTRODUCTION}

A hydroelectric dam was constructed in 1916 on the Muskegon River in the northern part of the city of Big Rapids, Michigan (fig. 1). This dam impounded water to a depth of about $17 \mathrm{ft}$. Aggradation of sediment from upstream sources after dam construction resulted in partial infilling of the dam pond. Removal of the upper $13 \mathrm{ft}$ of this dam in 1966 resulted in erosion and transport of an unknown volume of sediment from the impoundment area. Transport and deposition of these sediments substantially altered the downstream characteristics of the stream channel.

The city of Big Rapids plans to remove the remaining part (about $4 \mathrm{ft}$ ) of the dam foundation and restore the stream channel to natural conditions. Removal of the dam foundation will result in erosion and transport of additional sediment from the impoundment area. The city's water intake is currently installed behind a coffer dam, which is about $1,000 \mathrm{ft}$ downstream of the dam relic. The coffer dam maintains a reservoir that has the capacity to meet water-supply needs during periods of sustained low streamflow. Sediment released from the impoundment after the dam relic is demolished may partially fill the reservoir at the intake and reduce the storage capacity of the reservoir. The partially filled reservoir may not have the capacity to meet the city's water-supply needs.

In an effort to minimize the effect of erosion and subsequent deposition of sediment after demolition of the dam foundation, the city plans to dredge part of the sediment from the impoundment area. A plan also is being considered to construct a sediment trap near the city's water-treatment facility to collect sediment mobilized after dam removal. Information regarding the grain-size distribution of sediments is needed to develop a plan to manage the sediment likely to be mobilized after demolition of the dam foundation. 


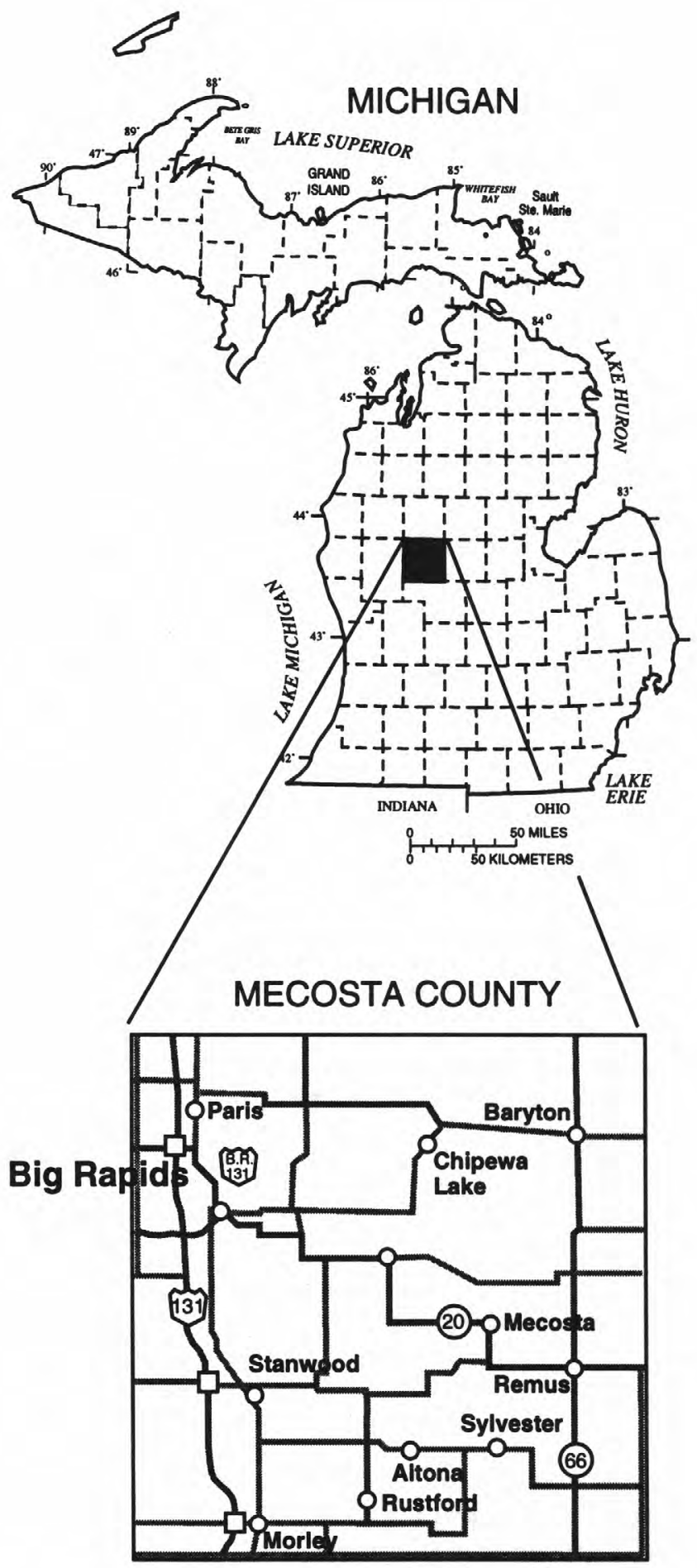

\section{CITY OF BIG RAPIDS}

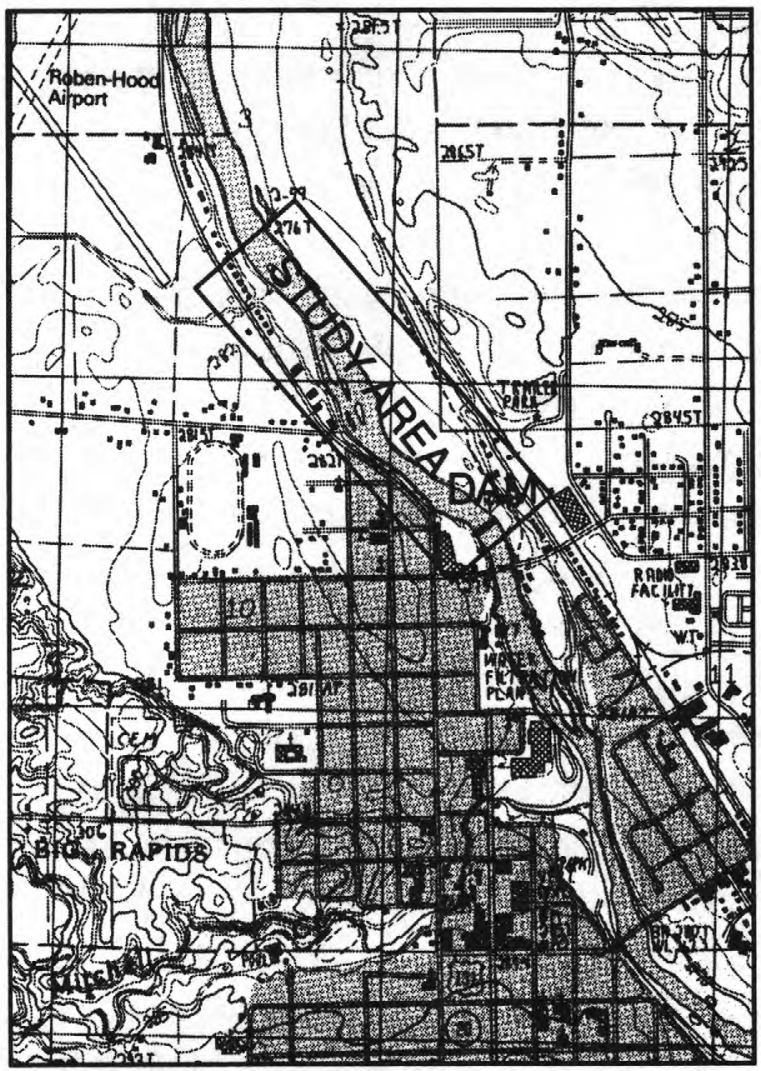

From USGS 7.5 Minute Series,Big Rapids, Michigan, Provisional Edition, 1985

Figure 1. State of Michigan, Mecosta County, and city of Big Rapids, Michigan. Area of study, denoted on city of Big Rapids map, extends about 4,000 feet upstream of Baldwin Street Bridge. 
The city also needs to delineate the configuration of the pre-dam stream channel, so that estimates of the volume of sediment captured in the impoundment area can be made.

The U.S. Geological Survey (USGS), in cooperation with the city of Big Rapids conducted a study to determine the character and size distribution of sediments in the impoundment area and to delineate the configuration of the pre-dam stream channel. Cores of stream sediments were collected and sieved and geophysical surveys (ground-penetrating radar profiles) were made during the summer of 1995.

The purposes of this report are to (1) describe the results of the sediment coring program and the geophysical surveys, (2) relate this information to the depositional history of sediments trapped behind the dam, and (3) provide an estimate of the volume of material that fills the pre-dam stream channel.

\section{HYDROGEOLOGIC SETTING}

The city of Big Rapids lies in the Muskegon River Valley in northwestern Mecosta County, Michigan (fig. 1). The Muskegon River occupies a large glacial meltwater channel, which formed in the interlobate zone between the Michigan and the Saginaw glacial-ice lobes during late Pleistocene time (Leverett and Taylor, 1915, p. 204). This meltwater channel is about 2 to $3 \mathrm{mi}$ wide near the city of Big Rapids (Farrand and Bell, 1982), and becomes progressively wider downstream.

The Muskegon River discharges into Lake Michigan and is one of the largest streams in the Great Lakes Basin. Average discharge of the Muskegon River during a 60-year period measured downstream from Big Rapids near Newaygo, Michigan, is about $1,900 \mathrm{ft}^{3} / \mathrm{s}$ (Miller and Twenter, 1986). Water from the Muskegon River is the sole source of water supply to the city of Big Rapids.

Maps that show the morphology and distribution of glacial landforms in Michigan (Martin, 1955; Farrand and Bell, 1982) indicate that the surficial deposits that border the Muskegon River east and west of city of Big Rapids are moraines ${ }^{1}$. The presence of numerous gravel pits on the moraine-like ridges that border the river, however, indicates that these features are not composed of glacial till and therefore are not moraines. Gravel pits on these ridges expose stratified deposits of sand and gravel, which are part of an extensive belt of glaciofluvial deposits that formed during stagnation deglaciation (Westjohn and others, 1994) in the interlobate zone between the Michigan and the Saginaw lobes of glacier ice.

\section{METHODS OF INVESTIGATION}

\section{Collection of Sediment Cores}

Sediment cores were collected from boreholes that were installed at 15 sites upstream from the dam foundation (fig. 2). A bucket auger was used to collect sediment cores and plastic casing was advanced ahead of the auger bucket to prevent sloughing of sediment into the boreholes. Lithologic descriptions of the cores are summarized in table 1. A total of $64.5 \mathrm{ft}$ of sediment was cored and representative samples of these cores were collected and sieved using U.S. Standard Sieves (table 2).

\section{Ground-Penetrating Radar Profiles}

Ground-penetrating radar (GPR) is a geophysical method that uses a high frequency electromagnetic (EM) pulse to investigate the subsurface. The method relies on the generation of a single-frequency EM pulse, which is triggered and sent by a transmitter antenna. The EM pulse penetrates Earth materials and is reflected at contacts between materials that have different physical properties. The reflected radar pulse is received at a second antenna (receiver antenna), and the traveltime of the EM pulse from transmitter to receiver is measured and recorded by a signalprocessing device.

\footnotetext{
${ }^{1}$ Moraine, as defined in Bates and Jackson (1987, p. 432), is a "Mound, ridge, or other distinct accumulation of unsorted, unstratified glacial drift, predominantly till, deposited chiefly by direct action of glacier ice, in a variety of topographic landforms that are independent of control by the surface on which the drift lies."
} 


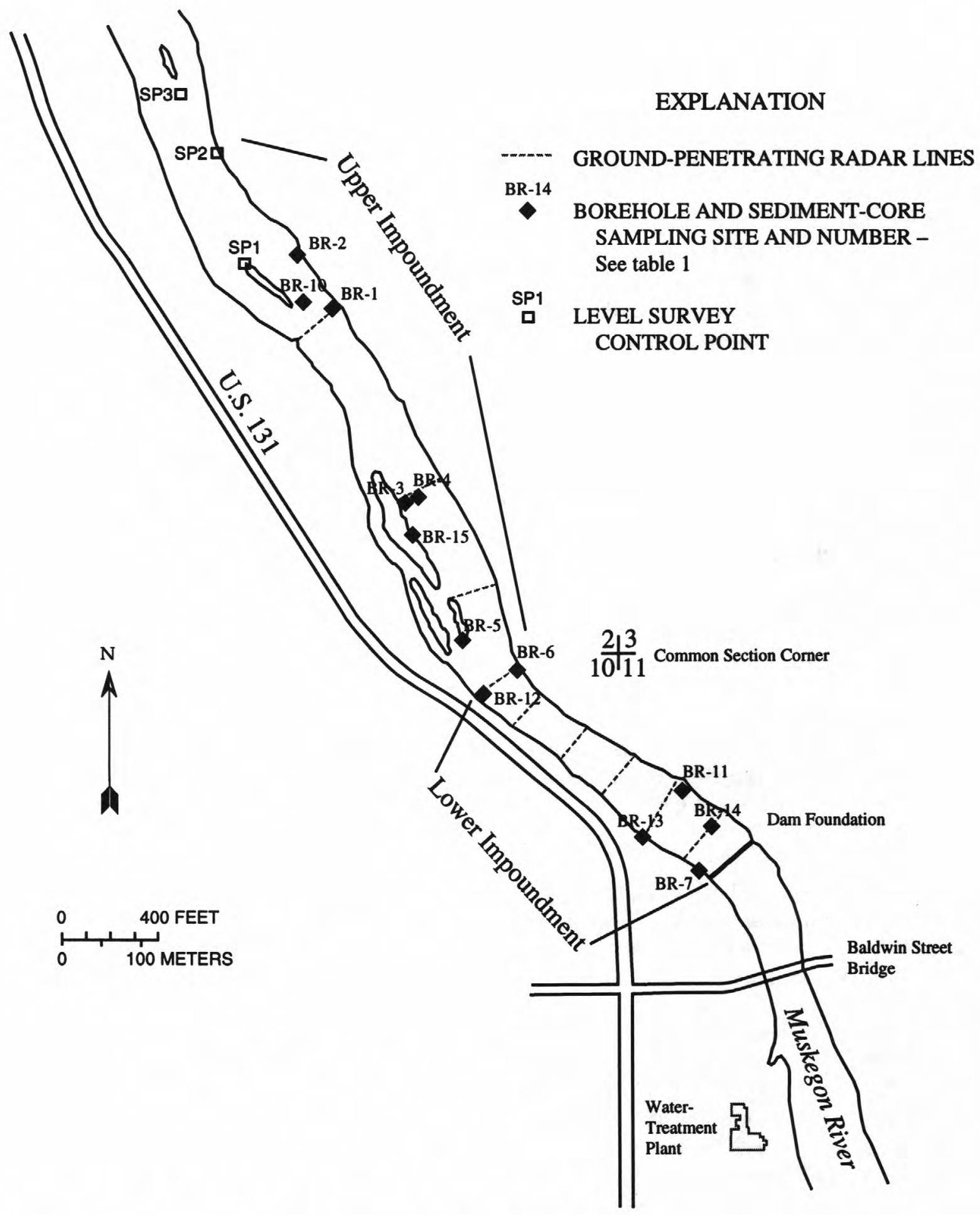

Figure 2. Data-collection sites and relevant features in the study area, Muskegon River, near Big Rapids, Michigan. 
Table 1. Lithologic descriptions of sediment cores collected at sites in the Muskegon River, Big Rapids, Michigan

\begin{tabular}{|c|c|c|c|}
\hline Lithology & $\begin{array}{c}\text { Thickness } \\
\text { (feet) }\end{array}$ & Lithology & $\begin{array}{c}\text { Thickness } \\
\text { (feet) }\end{array}$ \\
\hline Site BR-1 1 & & Site $\mathbf{B R}-11^{2}$ & \\
\hline 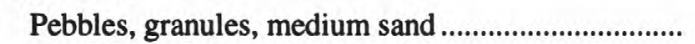 & 2.7 & Sand & 0.1 \\
\hline 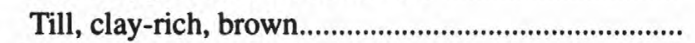 & 3.3 &  & 0.2 \\
\hline Site BR-2 & & 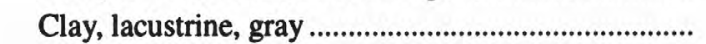 & 0.3 \\
\hline Sand, medium, well sorted.......................................... & 1.7 & Wood chips & 0.1 \\
\hline Sand, medium and coarse & 3.7 & 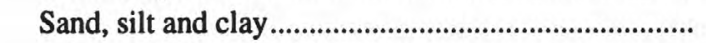 & 0.3 \\
\hline Site BR-3 ${ }^{2}$ & & Wood chips & 0.6 \\
\hline Sand, pebbles and wood chips & 1.5 & Sand and wood chips & 0.5 \\
\hline Terminated in cobbles at $1.5 \mathrm{ft}$ & & 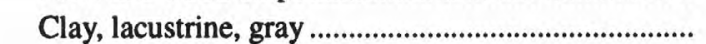 & 0.2 \\
\hline Site BR-4 & & 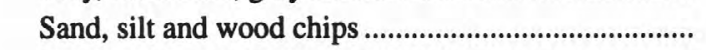 & 0.4 \\
\hline Sand, medium, and pebbles & 1.7 & 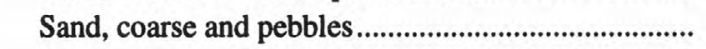 & 0.4 \\
\hline Till, clay-rich, brown & 1.3 & Pebbles, coarse sand & 2.8 \\
\hline 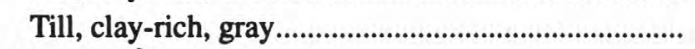 & 3.3 & Site BR-12 ${ }^{1}$ & \\
\hline Site BR-5 $\mathbf{5}^{2}$ & & Sand, coarse and medium, pebbles................................ & 1.9 \\
\hline Sand, medium, pebbles, and granules ........................... & 3.3 & Pebbles and coarse sand & 1.0 \\
\hline Terminated in cobbles at $3.3 \mathrm{ft}$ & & Till, clay-rich, brown & 0.4 \\
\hline Site BR-6 ${ }^{1}$ & & Terminated in cobbles in clay-rich till $3.3 \mathrm{ft}$ & \\
\hline Sand & 0.2 & Site BR-13 ${ }^{2}$ & \\
\hline Clay, lacustrine, gray & 1.2 & 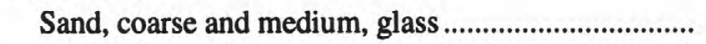 & 2.9 \\
\hline 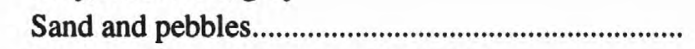 & 0.6 & Wood chips & 0.2 \\
\hline Sand, medium, fine sand and pebbles ......................... & 0.8 & 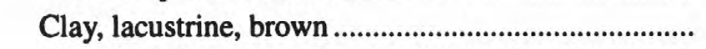 & 1.4 \\
\hline Sand, medium & 0.3 & Wood chips & 0.1 \\
\hline Clay, lacustrine, and wood chips................................. & 0.3 & Terminated in cobbles at $4.6 \mathrm{ft}$ & \\
\hline Sand, coarse, pebbles and wood chips & 0.2 & Site BR-14 ${ }^{2}$ & \\
\hline Till, clay-rich, brown & 1.9 & Sand, medium & 1.8 \\
\hline Site BR-7 $\mathbf{7}^{2}$ & & Clay, lacustrine, organic-rich, black ........................... & 0.3 \\
\hline Sand, well-sorted, pebbles & 1.6 & Wood chips & 0.7 \\
\hline Pebbles & 0.2 & Sand, medium & 0.4 \\
\hline Sand, coarse and medium, pebbles, wood chips........ & 0.4 & Wood chips & 0.7 \\
\hline 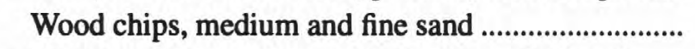 & 1.8 & Clay, lacustrine, gray & 0.2 \\
\hline \multirow{3}{*}{$\begin{array}{l}\text { Terminated in cobbles at } 4.1 \mathrm{ft} \text {. Sites BR- } 8 \text { and } \\
\text { BR-9 were cored } 2 \text { and } 4 \mathrm{ft} \text { west of BR-7; each } \\
\text { terminated in cobbles at same depth. }\end{array}$} & & Terminated in cobbles in alluvium at $4.1 \mathrm{ft}$ & \\
\hline & & Site BR-15 ${ }^{2}$ & \\
\hline & & 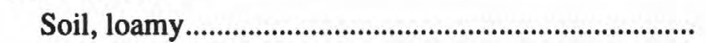 & 0.3 \\
\hline Site BR-10 ${ }^{2}$ & & Gravel and sand & 0.3 \\
\hline Sand, coarse and medium & 0.8 & 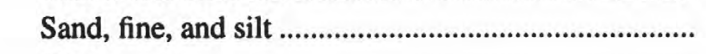 & 0.2 \\
\hline Gravel, granules, and coarse sand & 1.5 & Silt & 3.3 \\
\hline Terminated in cobbles at $2.3 \mathrm{ft}$ & & Terminated in cobbles at $4.1 \mathrm{ft}$ & \\
\hline
\end{tabular}

\footnotetext{
${ }^{1}$ Borehole ended in glacial till.

${ }^{2}$ Borehole ended in pre-dam alluvium.
}

The principal physical control of the propagation velocity of radar waves in Earth materials is the dielectric property or the dielectric constant of the material. The dielectric constant is a measure of the inductive capacity of an Earth material that results when an EM field is applied (Sheriff, 1984). This property differs as a function of lithology, water content, and specific conductance of pore water. 
Table 2. Sieve analysis of sediment cores collected at sites upstream of dam relic on the Muskegon River, Big Rapids, Michigan

[Numbers in parentheses reported in millimeters. $>$, actual value is greater than value shown]

\begin{tabular}{|c|c|c|c|c|c|c|c|c|}
\hline \multirow[b]{2}{*}{ Sample No. } & \multirow[b]{2}{*}{$\begin{array}{l}\text { Sample } \\
\text { length, } \\
\text { (feet) }\end{array}$} & \multicolumn{7}{|c|}{ Sieve size fraction, in inches } \\
\hline & & $\begin{array}{l}>0.5 \\
(12.7) \\
\text { pebble }\end{array}$ & $\begin{array}{c}>0.131 \\
(3.3) \\
\text { granule }\end{array}$ & $\begin{array}{c}>0.055 \\
(1.4) \\
\text { coarse sand }\end{array}$ & $\begin{array}{c}>0.039 \\
(1.0) \\
\text { coarse sand }\end{array}$ & $\begin{array}{c}>0.012 \\
(0.29) \\
\text { medium sand }\end{array}$ & $\begin{array}{c}>0.004 \\
(0.089) \\
\text { very fine } \\
\text { sand }\end{array}$ & $\begin{array}{c}>0.002 \\
(0.064) \\
\text { silt }\end{array}$ \\
\hline \multicolumn{9}{|c|}{ Percentage of sample in above range of size fractions } \\
\hline BR1-1 & 2.3 & 0.43 & 0.19 & 0.09 & 0.03 & 0.14 & 0.09 & 0.003 \\
\hline BR1-2 & .4 & .13 & .42 & .18 & .07 & .14 & .03 & .002 \\
\hline BR2-1 & 1.7 & $\left({ }^{1}\right)$ & $(1)$ & .003 & .003 & .89 & .11 & $\left({ }^{2}\right)$ \\
\hline BR2-2 & 3.6 & .02 & .10 & .20 & .11 & .47 & .10 & $\left({ }^{2}\right)$ \\
\hline BR3-1 & 1.5 & .16 & .29 & .04 & .01 & .39 & .10 & .005 \\
\hline BR4-1 & 1.8 & .35 & .11 & .02 & .03 & .36 & .12 & $\left({ }^{2}\right)$ \\
\hline BR5-1 & 3.3 & .28 & .24 & .08 & .02 & .33 & .06 & .002 \\
\hline BR7-1 & 2.2 & .24 & .06 & .06 & .03 & .57 & .04 & $\left(^{2}\right)$ \\
\hline BR7-2 & .4 & ${ }^{3} .29$ & 3.36 & ${ }^{3} .08$ & ${ }^{3} .02$ & .19 & .07 & $\left(^{2}\right)$ \\
\hline BR7-3 & .15 & ${ }^{3} .01$ & ${ }^{3} .13$ & ${ }^{3} .06$ & ${ }^{3} .03$ & .59 & .17 & .006 \\
\hline BR7-4 & .3 & ${ }^{3} .06$ & ${ }^{3} .12$ & ${ }^{3} .09$ & ${ }^{3} .04$ & .48 & .21 & .002 \\
\hline BR7-5 & .9 & ${ }^{3} .06$ & 3.28 & ${ }^{3} .16$ & ${ }^{3} .05$ & .27 & .18 & .003 \\
\hline BR11-2 & .3 & ${ }^{3} .13$ & ${ }^{3} .24$ & ${ }^{3} .15$ & ${ }^{3} .09$ & .56 & .22 & .001 \\
\hline BR11-3 & .3 & ${ }^{3} .39$ & 3.24 & ${ }^{3} .18$ & ${ }^{3} .01$ & .16 & .04 & .001 \\
\hline BR11-4 & .3 & 3.26 & 3.22 & ${ }^{3} .03$ & ${ }^{3} .16$ & .22 & $\left(^{2}\right)$ & $\left({ }^{2}\right)$ \\
\hline BR11-5 & .5 & ${ }^{3} .02$ & ${ }^{3} .10$ & ${ }^{3} .06$ & ${ }^{3} .03$ & .66 & .13 & $(2)$ \\
\hline BR11-6 & .3 & ${ }^{3} .20$ & ${ }^{3} .16$ & ${ }^{3} .08$ & ${ }^{3} .02$ & .23 & .31 & (2) \\
\hline BR11-9 & .4 & .37 & .09 & .03 & .02 & .44 & .06 & $(2)$ \\
\hline BR11-10 & 3.5 & .46 & .24 & .06 & .02 & .20 & .02 & .001 \\
\hline BR12-1 & 1.9 & .04 & .14 & .08 & .08 & .66 & .05 & $\left({ }^{2}\right)$ \\
\hline BR12-2 & 1.0 & .57 & .15 & .04 & $\left({ }^{1}\right)$ & .18 & .05 & $\left.{ }^{2}\right)$ \\
\hline BR13-1 & 2.9 & .10 & .41 & .25 & .08 & .06 & .09 & $(2)$ \\
\hline BR13-2 & .2 & ${ }^{3} .09$ & ${ }^{3} .27$ & ${ }^{3} .20$ & ${ }^{3} .05$ & .34 & .12 & .001 \\
\hline BR13-4 & .1 & ${ }^{3} .02$ & ${ }^{3} .13$ & ${ }^{3} .14$ & ${ }^{3} .07$ & .53 & .11 & .001 \\
\hline BR14-1 & 1.8 & $\left({ }^{1}\right)$ & .02 & $\left({ }^{1}\right)$ & $\left({ }^{1}\right)$ & .94 & .03 & $\left(^{2}\right)$ \\
\hline BR14-4 & .4 & $\left.{ }^{1}\right)$ & .02 & .02 & .46 & .39 & .11 & $\left(^{2}\right)$ \\
\hline BR14-5 & .7 & $\left({ }^{1}\right)$ & ${ }^{3} .26$ & ${ }^{3} .16$ & ${ }^{3} .04$ & .17 & .36 & .004 \\
\hline BR15-1 & .3 & .08 & .33 & .15 & .04 & .28 & .11 & $\left.{ }^{2}\right)$ \\
\hline BR15-2 & .2 & $\left({ }^{1}\right)$ & $\left({ }^{1}\right)$ & $\left({ }^{1}\right)$ & .53 & .46 & .01 & $\left(^{2}\right)$ \\
\hline BR15-3 & 2.1 & (1) & (1) & (1) & $\left({ }^{1}\right)$ & .86 & .10 & .04 \\
\hline
\end{tabular}

${ }^{1}$ Size fraction was not present in sieved sample.

${ }^{2}$ Size fraction was present in trace amount.

${ }^{3}$ Sample composed almost entirely of carbonized wood chips.

The GPR method relies on the measurement of the traveltime of EM waves, which are reflected from contacts between geologic materials that have a sufficient contrast in dielectric constant. The dielectric constant is related to the traveltime of radar waves by the following formula:

$$
t=\frac{2 \bullet d \bullet E_{r}}{c}{ }^{0.5},
$$




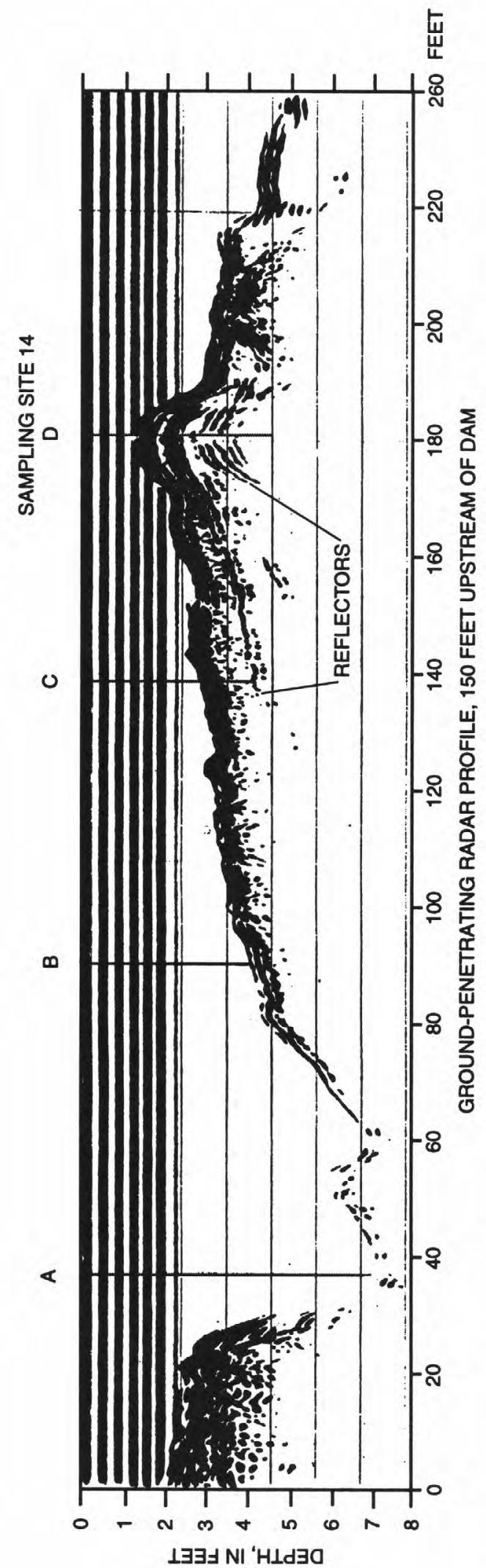

where

$t$ is traveltime of radar wave;
$d$ is depth to reflector;

General knowledge of sediment types present in the Muskegon River behind the dam at Big Rapids indicated that GPR methods had potential to delineate stratigraphy and the configuration of the pre-dam river channel. Visual inspection of bed material in the Muskegon River in the impoundment shows that it consists mostly of sand, gravel, cobbles, and boulders. Below this coarse sediment, lacustrine clay and silt should have been deposited in very low-flow to stagnant-water conditions, because the dam initially impounded water to a depth of about $17 \mathrm{ft}$. However, historical records indicate that prior to dam construction, a stretch of "white water" was present at and upstream from the dam site (Prein and Newhof, 1996). Bed material prior to dam construction probably consisted mostly of cobbles and boulders (Prein and Newhof, 1996). These types of geologic materials have a sufficient contrast in dielectric constants (Sheriff, 1984) to use GPR profiles as a means to delineate stratigraphy.

\footnotetext{
${ }^{2}$ Any use of trade, product, or firm names is for descriptive purposes only and does not imply endorsement by the U.S. Government.
} 
The streambed is the shallowest reflector in the Muskegon River, and radar reflections from this surface are on all GPR profiles. The water depth along the GPR profile lines ranged from about 2.5 to $7 \mathrm{ft}$ at the time of the surveys. In areas where water depth was greater than $4 \mathrm{ft}$, the radar signal was almost entirely attenuated by the water column, and the streambottom is the only reflector observed (see figure 3). Along profiles where the streambottom was from 2.5 to $4 \mathrm{ft}$ in depth, the GPR profiles typically show one or two faint reflecting horizons below the sediment/water interface.

Sediment cores collected from augered boreholes on GPR lines indicate that the depth of penetration of the radar signal was insufficient to adequately characterize the stratigraphy, or to define the morphology of the pre-dam stream channel. A combination of water depth and specific conductance of stream water (about $500 \mu \mathrm{S} / \mathrm{cm}$ during data collection) resulted in attenuation of the radar signal at shallow depths. Depth penetration of the GPR signal in the sediment column typically is less than $2 \mathrm{ft}$, whereas sediment cores show that alluvium captured in the impoundment area near the dam is about $4 \mathrm{ft}$ in thickness. The benefit of using GPR profiles is that they clearly show the configuration of the streambottom and water-depth calculations from GPR lines provide a basis for estimation of volume of sediment trapped in the lower impoundment area.

\section{STRATIGRAPHY AND SEDIMENTOLOGY}

Stratigraphic and sedimentologic relations of sediments in the Muskegon River vary as a function of distance upstream from the dam foundation. The impoundment can be divided into lower and upper areas on the basis of differences in the type of sedimentary fill. The lower impoundment is the area from the dam relic to about $1,300 \mathrm{ft}$ upstream, and the upper impoundment is the area that is 1,300 to about $3,500 \mathrm{ft}$ upstream of the dam (fig. 2).

In the lower impoundment, four distinct stratigraphic units were identified on the basis of examination of sediment cores. From the lower to the uppermost unit, they are (1) glacial till, (2) sand, gravel and cobbles, (3) cyclical, interbedded lacustrine clay, silt, and wood chips, and (4) sand, gravel, cobbles, boulders, and timber. The stratigraphic relation of these sediment types is illustrated in a diagrammatic geologic section (fig. 4). In the upper impoundment, the cyclical lacustrine deposits are absent, and typically, glacial till or very coarse pre-dam alluvium is overlain by post1966 sand and gravel.

\section{Glacial Till}

Pleistocene glacial till is the oldest geologic unit in the study area. Although the age of this material is unknown, this till is more than 13,000 years in age because it was deposited prior to the well defined and well dated Port Huron Moraine (Eschman, 1985). A segment of this moraine is about $60 \mathrm{mi}$ north of Big Rapids (Martin, 1955). This terminal moraine marks the southernmost reentrant position of the last Pleistocene ice sheet, which advanced into the upper part of the Lower Peninsula of Michigan, about 13,000 years ago (Eschman, 1985).

The areal extent of the glacial till in the impoundment area is unknown, as only four of the boreholes terminated in glacial till (see fig. 2 and table 1 ; sites 1, 4,6, and 12). Glacial deposits of this type are typically areally extensive, however, and till could be present at some depth at other sites where boreholes were installed. Several boreholes terminated in material too coarse to auger and glacial till could underlie this coarse sediment. Glacial till probably is areally extensive because this material is present on both sides of the river, near the dam foundation, and about 2,400 ft upstream from the dam foundation. Core samples from the four boreholes completed in glacial till are predominantly gray to brown, dense clay, with about 10 to 20 percent pebbles (table 1).

\section{Alluvium Deposited Prior to Dam Construction}

Alluvium that was deposited prior to dam construction probably consists mostly of coarse gravel and cobbles, with lesser amounts of medium to coarse sand. This material is likely to be pre-dam alluvium because these sediments are too coarse to have been transported into the impoundment area under low-flow to stagnant-water conditions. Ten of the 15 boreholes (table 1) terminated in coarse alluvium (gravel and cobbles) because the sediment was too large to enter the opening at the lead part of the auger bucket. 


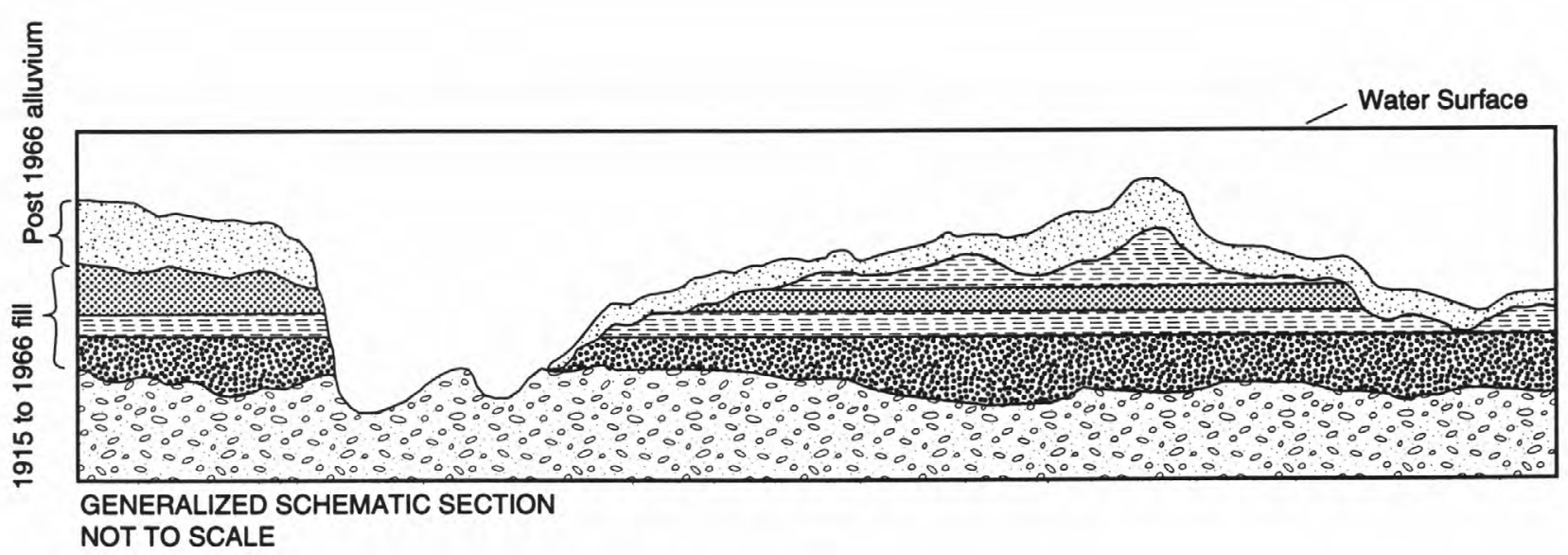

\section{EXPLANATION}

\begin{tabular}{|c|c|}
\hline$\therefore$ & ALLUVIUM - SAND, GRAVEL, BOULDERS, TIMBER/TREES, POST-1966 \\
\hline & WELL-SORTED SAND WITH WOOD CHIPS \\
\hline E亚严 & INTERBEDDED LACUSTRINE CLAY, SILT, AND WOOD CHIPS \\
\hline 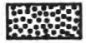 & COARSE ALLUVIUM - SAND, GRAVEL, COBBLES (PRE-DAM) \\
\hline & GLACIAL TILL \\
\hline
\end{tabular}

Figure 4. Stratigraphic relation of geologic units in the study area, interpreted on the basis of cores from boreholes, Muskegon River near Big Rapids, Michigan. Profile of streambottom is from ground-penetrating radar line 150 feet upstream of dam foundation.

\section{Lacustrine Deposits}

The dam as constructed in 1916 ponded water to a depth of about $17 \mathrm{ft}$. Sediments trapped in the pond area prior to 1966 consist of interbedded organic-rich lacustrine clay, gray lacustrine clay, wood chips and wood fibers, silt, and fine to medium sand. These materials were deposited in a repetitive, cyclical fashion related to different streamflow-velocity conditions. Typically, lacustrine clay is overlain by a composite of clay, wood fiber, and wood chips, which in turn is overlain by silt and sand. Beds of clay and wood chips are representative of sediment transport under nearstagnant conditions, which is likely the result of ice cover on the pond during winter months, followed by an influx of sediments ranging in size from silt to medium sand in spring, summer, and autumn. The stratigraphic relations of these deposits were determined on the basis of eight boreholes that penetrated the sedimentary sequence. The same stratigraphic relations were observed in a 6-foot vertical trench, which was excavated in a terrace about $1,200 \mathrm{ft}$ upstream from the dam foundation.
The thickness of lacustrine deposits ranges from 0 to $3.6 \mathrm{ft}$ (table 3 ). Lacustrine sediments were not observed in the current stream channel upstream from site 6 , which is about $1,300 \mathrm{ft}$ from the dam. The first three islands upstream from site 6 probably are composed partly of lacustrine deposits because $3.5 \mathrm{ft}$ of very well-sorted, fine to medium sand was cored at site 15 on the third island upstream from site 6 (fig. 2). This well-sorted sediment is indicative of the slightly higher streamflow velocities in the shallow upstream part of the pre-1966 impoundment.

\section{Coarse Alluvium}

Removal of the upper $13 \mathrm{ft}$ of the dam in 1966 resulted in erosion of most of the lacustrine deposits and subsequent aggradation of silt and coarser alluvium into the current impoundment. Thickness of coarse alluvium ranges from 0.1 to $5.4 \mathrm{ft}$ (table 3 ). The particle-size distribution of coarse alluvium was determined by sieve analyses. Sediment-size fractions for individual samples are shown in table 2 and the weighted average of sediment size on the basis of a composite of $24.4 \mathrm{ft}$ of sieved sample is shown in table 4. 
Table 3. Altitude of stream surface, sediment/water interface, and base of fill, and thickness of post-1966 fill, thickness of 1916-66 fill, and total thickness of fill at borehole sites in the impoundment behind the dam relic on the Muskegon River, Big Rapids, Michigan

[Altitudes in feet above sea level. Water level at dam relic face assumed at 890.6 feet on August 22, 1995. No., number; --, no data]

\begin{tabular}{rrrrrrr}
\hline $\begin{array}{c}\text { Bore- } \\
\text { hole } \\
\text { No. }\end{array}$ & $\begin{array}{c}\text { Alti- } \\
\text { tude of } \\
\text { water } \\
\text { surface }\end{array}$ & $\begin{array}{c}\text { Alti- } \\
\text { tude of } \\
\text { stream- } \\
\text { bottom }\end{array}$ & $\begin{array}{c}\text { Alti- } \\
\text { tude of } \\
\text { base of } \\
\text { fill }\end{array}$ & $\begin{array}{c}\text { Thick- } \\
\text { ness of } \\
\text { post- } \\
\text { 1966 fill } \\
\text { (feet) }\end{array}$ & $\begin{array}{c}\text { Thick- } \\
\text { ness of } \\
\text { 1916- } \\
\text { 66 fill } \\
\text { (feet }\end{array}$ & $\begin{array}{c}\text { Total } \\
\text { thick- } \\
\text { ness of } \\
\text { till } \\
\text { (feet) }\end{array}$ \\
\hline 1 & 891.3 & 889.9 & 887.2 & 2.7 & 0 & 2.7 \\
2 & 891.3 & 888.2 & -- & 5.4 & 0 & 5.4 \\
3 & 891.2 & 888.2 & -- & 1.5 & 0 & 1.5 \\
4 & 891.2 & 887.8 & 886.1 & 1.7 & 0 & 1.7 \\
5 & 890.9 & 889.3 & -- & 3.3 & 0 & 3.3 \\
6 & 890.8 & 890.6 & 887.0 & .2 & 3.4 & 3.6 \\
7 & 890.6 & 888.4 & 884.3 & 1.8 & 2.3 & 4.1 \\
10 & 891.3 & 888.2 & -- & 2.3 & 0 & 2.3 \\
11 & 890.6 & 888.4 & 885.7 & .1 & 2.6 & 2.7 \\
12 & 890.8 & 888.0 & 885.1 & 2.9 & 0 & 2.9 \\
13 & 890.6 & 888.6 & 884.0 & 2.9 & 1.7 & 4.6 \\
14 & 890.6 & 888.9 & 884.8 & 1.8 & 2.3 & 4.1 \\
15 & 891.0 & 1891.6 & 887.5 & .6 & 3.5 & 4.1 \\
\hline
\end{tabular}

${ }^{1}$ Borehole 15 is on an island, and given altitude is of land surface, which is 0.6 feet above stream surface.

Table 4. Weighted average of sediment-size fractions of post-1966 alluvium in the Muskegon River, Big Rapids, Michigan

[Total of 24.4 feet of core sieved. Numbers in parentheses reported in millimeters]

\begin{tabular}{|c|c|c|c|c|c|c|}
\hline \multicolumn{7}{|c|}{ Sieve size fraction, in inches } \\
\hline $\begin{array}{c}>0.5 \\
(12.7) \\
\text { pebble }\end{array}$ & $\begin{array}{c}>0.131 \\
(3.3) \\
\text { granule }\end{array}$ & $\begin{array}{c}>0.055 \\
(1.4) \\
\text { coarse } \\
\text { sand }\end{array}$ & $\begin{array}{c}>0.039 \\
(1.0) \\
\text { coarse } \\
\text { sand }\end{array}$ & $\begin{array}{c}>0.012 \\
(0.29) \\
\text { medium } \\
\text { sand }\end{array}$ & $\begin{array}{c}>0.004 \\
(0.089) \\
\text { very } \\
\text { fine } \\
\text { sand }\end{array}$ & $\begin{array}{c}>0.002 \\
(0.064) \\
\text { silt }\end{array}$ \\
\hline
\end{tabular}

Percentage of sample in above range of size fractions

\begin{tabular}{lllllll}
0.179 & 0.170 & 0.098 & 0.050 & 0.429 & 0.075 & 0.001 \\
\hline
\end{tabular}

In order of decreasing abundance, size fractions (weighted average of $24.4 \mathrm{ft}$ of core) of the composite sample are medium sand ( 43 percent), pebbles (18 percent), granules (17 percent), coarse sand
(15 percent), very fine sand ( 8 percent), and silt (0.1 percent). These descriptors of sediment size are from Pettijohn and others (1987, p. 72). The weighted average is biased toward pebble-size and smaller fractions because the average does not include size fractions larger than pebbles. These coarser materials could not be sampled with a bucket auger.

The bed of the Muskegon River in the study area is littered with cobbles, boulders, and timber. The cobbles, boulders, and timber are the likely result of transport by winter ice jams rather than being part of the active bedload.

\section{DELINEATION OF IMPOUNDMENT AREA}

The extent of the impoundment related to the dam foundation was determined by level and stadia rod survey. Altitudes of the stream surface and sediment/water interface were measured at augered boreholes; the altitude of the stream surface also was measured at three locations upstream of the boreholes (fig. 2).

The gradient of the Muskegon River is nearly flat $(0.0002 \mathrm{ft} / \mathrm{ft}$ ) from the dam to borehole 6 (see BR-6, fig. 2), which is about $1,300 \mathrm{ft}$ upstream. The gradient is slightly steeper from 1,300 to about $3,200 \mathrm{ft}$ upstream $(0.0003 \mathrm{ft} / \mathrm{ft})$, and abruptly increases from 3,200 to $3,500 \mathrm{ft}$, where the gradient is about $0.0008 \mathrm{ft} / \mathrm{ft}$. Along this $300 \mathrm{ft}$ stretch of the stream, riffles are present and the streambed consists mostly of cobbles and boulders. On the basis of this information, the upper extent of the current impoundment is assumed to be about $3,500 \mathrm{ft}$ upstream of the dam foundation.

The extent of the pre-1966 impoundment that was formed by the original dam could not be determined. Lacustrine sediments that would allow delineation of the former impoundment were eroded from the active part of the stream channel after the upper part of the dam was removed in 1966. However, a flat former stream terrace extends about $9,000 \mathrm{ft}$ upstream, and this feature probably is a product of the former impoundment. 


\section{ESTIMATE OF SEDIMENT VOLUME IN THE LOWER IMPOUNDMENT}

The fine-grained lacustrine sediments and wood chips, which were captured behind the dam during 1916-66, are the principal concern of Big Rapids city officials. These sediments are present in the area from the dam foundation to about $1,300 \mathrm{ft}$ upstream, or to the general vicinity of borehole 6 (fig. 2). Most of these sediments would be difficult, if not impossible, to capture after the dam foundation is removed, regardless of the type of sediment trap designed and installed. This is principally because silt- and clay-size sediments would remain in suspension even under low-flow conditions. The wood chips also would remain in suspension under low-flow conditions because they are water saturated and have about the same density as water. The plan being considered by city officials is to dredge these sediments from the impoundment area prior to removing the dam foundation.

The volume of sediments captured in the lower part of the impoundment area can be estimated because the thickness of sedimentary fill is known from sediment cores collected from boreholes. Four boreholes were augered near the two GPR profiles just upstream from the dam foundation (fig. 2; sites 7, 11, 13, and 14). Boreholes 6 and 12 were augered near a GPR line at the upper end of the lower impoundment (fig. 2). All these boreholes ended in pre-dam coarse alluvium or glacial till. Thickness of sediments above the pre-dam streambottom in the area of the lower impoundment range from 2.7 to $4.6 \mathrm{ft}$ (table 3).

No boreholes were augered in the river reach from about 600 to $1,200 \mathrm{ft}$ upstream of the dam foundation because water depths typically were about $4 \mathrm{ft}$ or deeper. Sediment thickness in this reach was estimated on the basis of projection of thickness from boreholes 13 to 12 , and boreholes 11 to 6 .

The altitudes of the stream surface and sediment/water interface at each borehole site were determined by level surveys. Altitude of the pre-dam river channel at each site was determined by subtracting the thickness of sediments from the altitude of the sediment/water interface (table 3). GPR surveys were used to determine depth of water along profile lines and altitudes of the sediment/water interface. Altitudes of the base of lacustrine sediments were extrapolated from these data. Where water depths exceed thickness of sediments captured by the lower impoundment, the current channel is assumed to be below the pre-dam streambottom.

The composite thickness of lacustrine sediments and overlying post-1966 coarse alluvium in the lower impoundment area is shown in figure 5. This map of sediment thickness was used to compute the volume of material that has been captured since the dam was constructed. Areas within closed contour lines and areas between adjacent contour lines (see fig. 5 , areas labeled A1 through A12) were digitized, and the number of square feet within each of the areas was computed. These measured areas were used in conjunction with average sediment thickness per digitized area to compute volume of sediments for each. The total sediment volume in the lower impoundment estimated by this method is about $19,000 \mathrm{yd}^{3}$ (table 5 ).

Table 5. Estimate of volume of sediment in the lower impoundment area, Muskegon River, Big Rapids, Michigan

[A1-A12 areas used in volume calculations are shown on fig. 5 . ft, foot; $\mathrm{ft}^{2}$, square foot; $\mathrm{ft}^{3}$, cubic foot]

\begin{tabular}{lccr}
\hline Area & $\begin{array}{c}\text { Actual area } \\
\left(\mathrm{ft}^{2}\right)\end{array}$ & $\begin{array}{c}\text { Average } \\
\text { thickness of } \\
\text { sediment in } \\
\text { digitized area } \\
(\mathrm{ft})\end{array}$ & $\begin{array}{r}\text { Volume of } \\
\text { sediment in } \\
\text { digitized area } \\
\left(\mathrm{ft}^{3}\right)\end{array}$ \\
\hline A1 & 7,800 & 4 & 31,200 \\
A2 & 51,800 & 3.5 & 181,300 \\
A3 & 41,440 & 2.5 & 103,600 \\
A4 & 30,120 & 1.5 & 45,180 \\
A5 & 38,480 & .5 & 19,240 \\
A6 & 8,800 & 4 & 36,480 \\
A7 & 2,200 & 3.5 & 7,700 \\
A8 & 5,080 & 3 & 15,240 \\
A9 & 18,120 & 2.5 & 45,300 \\
A10 & 3,320 & 1.5 & 4,980 \\
A11 & 1,680 & 1 & 1,680 \\
A12 & 22,800 & 1 & 22,880 \\
& Total volume of sediment $\ldots \ldots \ldots \ldots \ldots . .$. & 514,780 \\
& & & $19,065 \mathrm{yd}$ \\
\hline
\end{tabular}




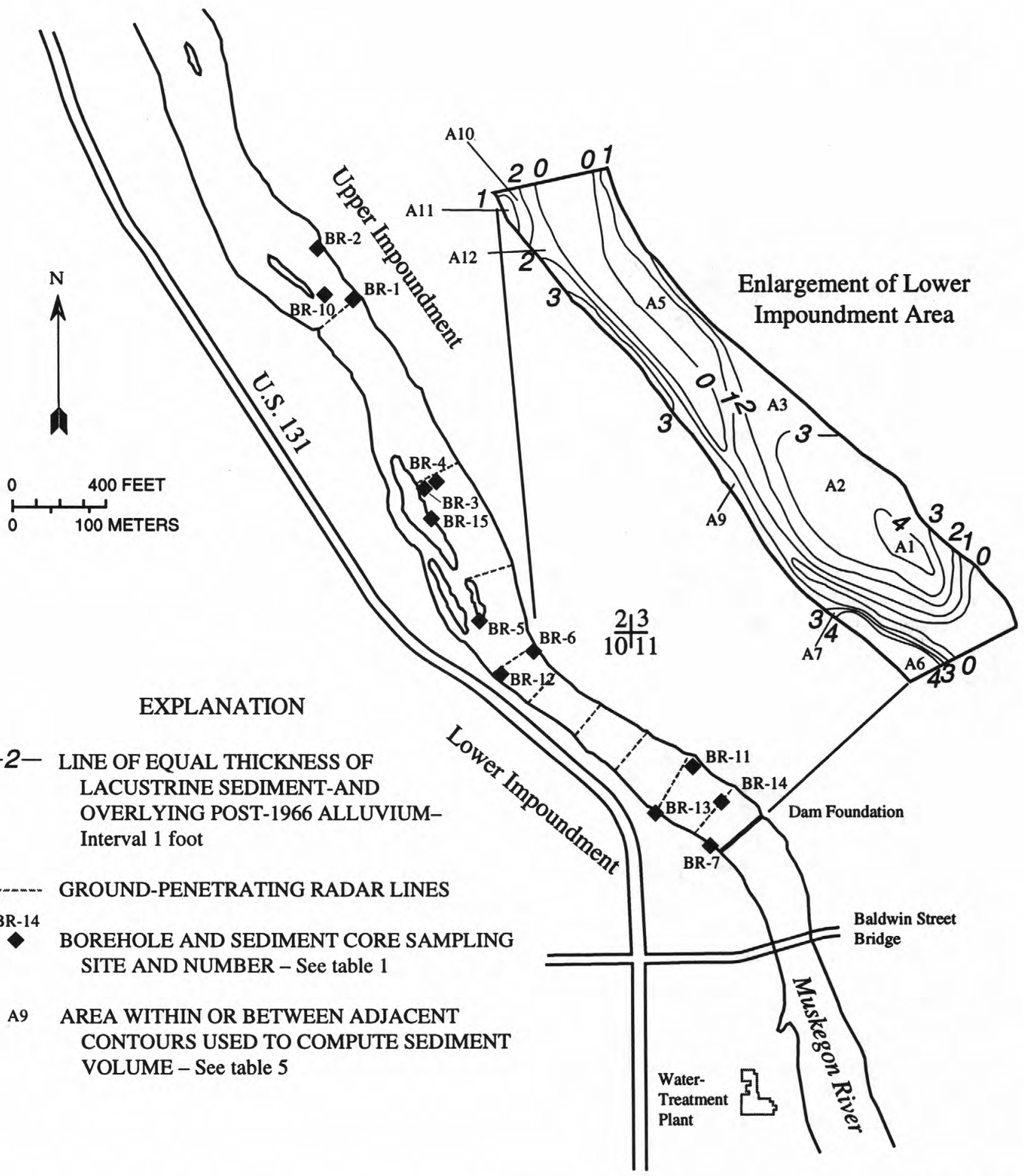

Figure 5. Line of equal composite thickness of lacustrine sediments and younger coarse alluvial fill captured behind the dam relic on the Muskegon River, near Big Rapids, Michigan. 


\section{SUMMARY}

Sediment cores were collected at 15 sites upstream from a dam relic on the Muskegon River, near Big Rapids, Michigan. Examination and sieve analysis of core samples form the principal basis for interpreting the sedimentation history and stratigraphy from 1916 to the present. Ground-penetrating radar surveys were made to develop profiles of the streambottom.

- Two distinct types of sediment are impounded behind the dam relic: older lacustrine sediment that was captured during 1916-66, and post-1966 sediments that have been deposited on an erosional surface, which was created by removal of the upper part of the dam in 1966.

- The older sediments (1916-66) consist of cyclical deposits of lacustrine clay, wood chips, silt, and sand. Multiple layers of these materials reflect seasonal changes in streamflow velocity. Layers of clay and wood chips were deposited during noflow conditions, probably in winter when the pond behind the dam was ice covered. Interbeds of silt and sand were deposited during spring, summer, or autumn.

- The post-1966 sediment is mostly sand and gravel that aggraded onto an erosional surface. This erosional surface is related to stream-gradient changes produced by removal of the upper $13 \mathrm{ft}$ of the dam.

- The pre-dam streambottom is reasonably well defined in an area that extends to about $1,300 \mathrm{ft}$ upstream of the dam relic. In this lower impoundment area, sediments that underlie the 1916-66 fill consist of sand, gravel, cobbles, and probably boulders. The presence of cobbles or coarser sediment precluded coring of this material in most areas. This material is likely pre-dam alluvium, because it is too coarse to have been deposited in the lowflow to stagnant-water conditions behind the original dam.

- The fine-grained cyclical lacustrine sediments are not present upstream from the lower impoundment area, with the exception that the three islands at about 1,500 to $2,300 \mathrm{ft}$ upstream of the dam consist almost entirely of fine sand and silt deposited during 1916-66. These sediments most likely were deposited under near-constant stream-velocity conditions because of the degree of sorting of this material.

- The stream gradient in the lower impoundment area is small $(0.0002 \mathrm{ft} / \mathrm{ft})$. The gradient increases slightly $(0.0003 \mathrm{ft} / \mathrm{ft})$ from 1,300 to $3,200 \mathrm{ft} / \mathrm{ft}$ in the upper impoundment. The stream gradient changes abruptly $(0.0008 \mathrm{ft} / \mathrm{ft})$ in the area that extends from 3,200 to $3,500 \mathrm{ft}$ upstream. The dam relic probably has little if any control on sedimentation in the area that is more than $3,500 \mathrm{ft}$ upstream.

- Sediments in the upper part of the impoundment $(1,300$ to about $3,500 \mathrm{ft}$ upstream of the dam) are almost entirely sand and gravel; cobbles and boulders on the streambottom in this area (and in the lower part of the impoundment) probably are the product of transport by ice jams.

- The pre-dam streambottom in the upper part of the impoundment cannot be delineated with any degree of certainty, because post-1966 sediments and pre-1916 sediments cannot be differentiated from each other. However, most cores in the upper impoundment end in material too coarse to auger through. This coarse material probably is alluvium deposited prior to dam construction, and may be remnants of the pre-dam channel bottom.

- GPR surveys were used to delineate streambottom profiles. Water-depth calculations from GPR profiles provide a basis for estimation of sediment volume captured in the lower impoundment area. GPR profiles did not provide conclusive data that could be used to map stratigraphy and characterize the nature of the pre-dam streambottom because of insufficient penetration of the radar signal. The signal was almost entirely attenuated by the water column in areas where depth to the sediment-water interface was more than $4 \mathrm{ft}$. In areas where depth of water was less than $4 \mathrm{ft}$, the radar signal was attenuated in the upper $2 \mathrm{ft}$ of the sediment column. Analysis of cores from boreholes augered on or near GPR profile lines indicate that sediments captured by the dam foundation are 2.7 to more than $4 \mathrm{ft}$ in thickness. On the basis of core analyses, it is concluded that penetration depth of radar waves was insufficient to "see" below the uppermost layer of sediment, which in most areas is post-1966 sand and gravel.

- The total volume of sediments impounded upstream of the dam relic (post-1916 sediments) in the lower impoundment area is about $19,000 \mathrm{yd}^{3}$. 


\section{REFERENCES CITED}

Bates, R.L., and Jackson, J.A., eds., 1987, Glossary of Geology (3d ed.): Alexandria, Va., American Geological Institute, $788 \mathrm{p}$.

Eschman, D.F., 1985, Summary of the Quaternary history of Michigan, Ohio, and Indiana: Journal of Geological Education, v. 33, no. 5, p. 26.

Farrand, W.R., and Bell, D.L., 1982, Quaternary geology of southern Michigan: Ann Arbor, Mich., Department of Geological Sciences, University of Michigan, scale $1: 500,000$.

Geophysical Survey Systems, Inc., 1974, Continuous subsurface profiling by impulse radar: Hudson, New Hampshire, Geophysical Survey Systems, Inc., 20 p.

Leveret, Frank, and Taylor, F.B., 1915, The Pleistocene of Indiana and Michigan and history of the Great Lakes: U.S. Geological Survey Monograph 53, 529 p.

Martin, H.M., 1955, Map of the surface formations of the southern peninsula of Michigan: Michigan Geological Survey, Publication 49, scale 1:500,000.
Miller, J.B., and Twenter, F.R., 1986, Michigan surfacewater resources, in Moody, D.W., Chase, E.B., and Aronson, D.A., compilers, National Water Summary 1985-Hydrologic events and surface-water relations: U.S. Geological Survey Water-Supply 2300, p. 277-284.

Pettijohn, F.J., Potter, P.E., and Siever, Raymond, 1987, Sand and sandstone: New York, Springer-Verlag, 553 p.

Prein and Newhof, 1996, Draft feasibility study removal of dam remnant. [Consultant's compilation of historical data, numerous sources].

Sheriff, R.E., compiler, 1984, Encyclopedic dictionary of exploration geophysics ( $2 \mathrm{~d}$ ed.): Tulsa, Oklahoma, Society of Exploration Geophysics, 323 p.

Westjohn, D.B., Weaver, T.L., and Zacharias, K.F., 1994, Hydrogeology of Pleistocene glacial deposits and Jurassic "red beds" in the central Lower Peninsula of Michigan: U.S. Geological Survey Water-Resources Investigations Report 93-4152, 14 p. 



\section{Chief, Michigan District \\ U.S. Geological Survey}

Water Resources Division

6520 Mercantile Way, Suite 5

Lansing, MI 48911 